\title{
COMMENTARY
}

\section{Fluid resuscitation should respect the endothelial glycocalyx layer}

\author{
Bertrand Guidet ${ }^{1,2,3^{*}}$ and Hafid Ait-Oufella $a^{1,2,4}$ \\ See related research by Chappell et al., http://ccforum.com/content/18/5/538
}

\begin{abstract}
Endothelial glycocalyx degradation induced by fluid overload adds to the concern of a detrimental effect of uncontrolled fluid resuscitation and the risk of unnecessary fluid infusion. As a consequence, the use of new tools for monitoring response to fluids appears promising. From that perspective, the monitoring of plasma concentration of glycocalyx degradation markers could be useful.
\end{abstract}

Fluid resuscitation is common practice for patients with hypovolemia and is recommended as first-line treatment for septic shock. However, accumulating evidence suggests that uncontrolled fluid loading may be detrimental. In that respect, the study by Chappell and colleagues [1] in the previous issue of Critical Care adds an important piece of information to the debate over the need for careful monitoring of patients in order to avoid unnecessary fluids.

During peri-operative management, Chappell and colleagues prospectively explored the consequences of acute volume loading on endothelial functions and hypothesized that high-volume infusion could alter endothelial glycocalyx. The glycocalyx consists of a variety of endothelial membrane-bound molecules, including glycoproteins and proteoglycans that form a negatively charged barrier to circulating cells and macromolecules [2]. Numerous animal studies have demonstrated that destruction of the glycocalyx (using enzymatic approaches, for example) leads to increased capillary permeability [3]. In vivo, degradation of the glycocalyx with heparinase favors tight contacts

\footnotetext{
* Correspondence: bertrand.guidet@sat.aphp.fr

${ }^{1}$ Assistance Publique - Hôpitaux de Paris, Hôpital Saint-Antoine, Service de Réanimation Médicale, 184 rue du Faubourg Saint Antoine, Paris F-75012, France

${ }^{2}$ Sorbonne Universités, UPMC Univ Paris 06, UMR_S 1136, Institut Pierre Louis d'Epidémiologie et de Santé Publique, 47-83 Boulevard de l'hôpital, Paris 75013, France

Full list of author information is available at the end of the article
}

between circulating leukocytes and the endothelium through denudation of the protective barrier that normally prevents this effect [4]. In addition, the glycocalyx participates in the coagulation process as heparan sulfate and dermatan sulfate, two glycocalyx glycosaminoglycans, potentiate the activity of two anticoagulant enzymes: antithrombin III (by a factor of 100) and heparin cofactor II, respectively (reviewed in [5]).

Chappell and colleagues reported that volume loading (20 $\mathrm{mL} / \mathrm{kg}$ of hydroxyethyl starch (HES) 130/0.4) in elective surgery induced a release of atrial natriuretic peptide (ANP) associated with an increase of serum glycocalyx components (syndecan-1 and hyaluronan) but that there was no effect of acute normovolemic hemodilution. The augmentation of these plasma components suggests a degradation of endothelial glycocalyx that could promote vascular leakage, leukocyte adhesion, and procoagulant status. However, this is a speculative and physiopathological conclusion, and the authors did not provide any direct evidence of glycocalyx functional alteration. The twofold increase of serum syndecan-1 concentration after volume overload is statistically significant but was very far from the 10-fold increase reported during septic shock [6] and the 40-fold increase after aortic surgery [7].

The mechanisms of glycocalyx shedding have not been directly investigated, but the authors proposed that ANP could be implicated. This hypothesis is based on a previous experimental study by the same group [8] and the observation of a simultaneous plasma increase of ANP and glycocalyx components during volume overload. Other mechanisms of shedding have been proposed [5], such as the activation of circulating enzymes (heparinase, neuraminidase, and pronase), the release of pro-inflammatory cytokines (tumor necrosis factor-alpha), or the direct effect of increased shear stress on the arterial endoluminal wall. Finally, reactive oxygen species could also induce glycosaminoglycans release. As albumin has anti-oxidant properties [9], one can speculate that volume resuscitation using 
human albumin could be less harmful than HES. A recent trial suggests that albumin could reduce mortality in the most severe cases of septic shock [10]. The mechanisms of the potential beneficial effect of albumin remain unclear. An interaction of albumin with the glycocalyx leading to a reduction of the capillary leak is a seductive hypothesis but should be further investigated [11].

This translational study gives interesting insights into the deleterious effects of fluid infusion in critically ill patients. Indeed, accumulative clinical studies pointed out that positive fluid balance and weight gains are associated with a worse prognosis [12] but the mechanisms of this deleterious effect remain unknown. Fluid accumulation within the tissue could alter the diffusion of oxygen, promoting hypoxic cellular injury. Fluid resuscitation is recommended as a first-line treatment, particularly during the first hour [13], but the volume and type of fluid that should be used remain controversial. The choice of fluid should be integrated in a dynamic process (rescue, optimization, stabilization, and de-escalation) [14]. Recent trials have added to the confusion regarding the usefulness of an algorithm guiding hemodynamic management of shock [15] and the mean arterial pressure that should be targeted [16]. Three criteria should be present: evidence of fluid responsiveness such as pulse pressure variation; presence of signs of tissue hypoperfusion; and absence of fluid overload. Stopping rules are either no fluid responsiveness or absence of signs of tissue hypoperfusion or presence of fluid overload. We need to set clinically relevant goals. From that perspective, an integrative approach looking at simple indices of tissue perfusion and microcirculation could be useful at the bedside $[17,18]$, although so far no interventional study has proven that such a strategy is able to improve the outcome. The protection or restoration of glycocalyx might be considered an important goal [19]. The place of glycocalyx degradation components remains to be assessed, but they could represent a surrogate marker for physicians to identify vascular endothelial injury and ultimately to limit fluid overload. A respectful strategy for the glycocalyx may decrease the capillary leak and improve tissue oxygenation just by giving the right amount of fluids and maybe by choosing fluids with no impact on glycocalyx degradation.

\section{Abbreviations}

ANP: Atrial natriuretic peptide; HES: Hydroxyethyl starch.

\section{Competing interests}

The authors declare that they have no competing interests.

\section{Author details}

${ }^{1}$ Assistance Publique - Hôpitaux de Paris, Hôpital Saint-Antoine, Service de Réanimation Médicale, 184 rue du Faubourg Saint Antoine, Paris F-75012. France. ${ }^{2}$ Sorbonne Universités, UPMC Univ Paris 06, UMR_S 1136, Institut Pierre Louis d'Epidémiologie et de Santé Publique, 47-83 Boulevard de I'hôpital, Paris 75013, France. ${ }^{3}$ INSERM, UMR_S 1136, Institut Pierre Louis
d'Epidémiologie et de Santé Publique, 47-83 Boulevard de l'hôpital, Paris 75013, France. ${ }^{4}$ Inserm U970 PAris Research Cardiovascular Center (PARCC), 56 rue Leblanc, Paris 75015, France.

Published online: 23 December 2014

\section{References}

1. Chappell D, Bruegger D, Potzel J, Jacob M, Brettner F, Vogeser M, Conzen P, Becker BF, Rehm M: Hypervolemia increases release of atrial natriuretic peptide and shedding of the endothelial glycocalyx. Crit Care 2014, 18:538.

2. Henry CB, Duling BR: Permeation of the luminal capillary glycocalyx is determined by hyaluronan. Am J Physiol 1999, 277:H508-H514.

3. Jacob M, Bruegger D, Rehm M, Welsch U, Conzen P, Becker BF: Contrasting effects of colloid and crystalloid resuscitation fluids on cardiac vascular permeability. Anesthesiology 2006, 104:1223-1231.

4. Constantinescu AA, Vink H, Spaan JA: Endothelial cell glycocalyx modulates immobilization of leukocytes at the endothelial surface. Arterioscler Thromb Vasc Biol 2003, 23:1541-1547.

5. Ait-Oufella H, Maury E, Lehoux S, Guidet B, Offenstadt G: The endothelium: physiological functions and role in microcirculatory failure during severe sepsis. Intensive Care Med 2010, 36:1286-1293.

6. Nelson A, Berkestedt I, Schmidtchen A, Ljunggren L, Bodelsson M: Increased levels of glycosaminoglycans during septic shock: relation to mortality and the antibacterial actions of plasma. Shock 2008, 30:623-627.

7. Rehm M, Bruegger D, Christ F, Conzen P, Thiel M, Jacob M, Chappell D, Stoeckelhuber M, Welsch U, Reichart B, Peter K, Becker BF: Shedding of the endothelial glycocalyx in patients undergoing major vascular surgery with global and regional ischemia. Circulation 2007, 17:1896-1906.

8. Bruegger D, Jacob M, Rehm M, Loetsch M, Welsch U, Conzen P, Becker BF: Atrial natriuretic peptide induces shedding of endothelial glycocalyx in coronary vascular bed of guinea pig hearts. Am J Physiol Heart Circ Physiol 2005, 5:1993-1999

9. Taverna M, Marie AL, Mira JP, Guidet B: Specific antioxidant properties of human serum albumin. Ann Intensive Care 2013, 3:4.

10. Caironi P, Tognoni G, Masson S, Fumagalli R, Pesenti A, Romero M, Fanizza C, Caspani L, Faenza S, Grasselli G, lapichino G, Antonelli M, Parrini V, Fiore G, Latini R, Gattinoni L, ALBIOS Study Investigators: Albumin replacement in patients with severe sepsis or septic shock. N Engl J Med 2014, 370:1412-1421.

11. Vincent JL, Russell J, Jacob M, Martin G, Guidet B, Wernerman J, Ferrer Roca R, McCluskey S, Gattinoni L: Albumin administration in the acutely ill: what's new and where next? Crit Care 2014, 18:231.

12. Boyd JH, Forbes J, Nakada TA, Walley KR, Russell JA: Fluid resuscitation in septic shock: a positive fluid balance and elevated central venous pressure are associated with increased mortality. Crit Care Med 2011, 39:259-265.

13. Waechter J, Kumar A, Lapinsky SE, Marshall J, Dodek P, Arabi Y, Parrillo JE, Dellinger RP, Garland A, Cooperative Antimicrobial Therapy of Septic Shock Database Research Group: Interaction between fluids and vasoactive agents on mortality in septic shock: a multicenter, observational study. Crit Care Med 2014, 42:2158-2168.

14. Raghunathan K, Murray PT, Beattie WS, Lobo DN, Myburgh J, Sladen R, Kellum JA, Mythen MG, Shaw AD, ADQI XII Investigators Group: Choice of fluid in acute illness: what should be given? An international consensus Br J Anaest 2014, 5:772-783.

15. Investigators PCESS, Yealy DM, Kellum JA, Huang DT, Barnato AE, Weissfeld LA, Pike F, Terndrup T, Wang HE, Hou PC, LoVecchio F, Filbin MR, Shapiro $\mathrm{NI}$, Angus DC: A randomized trial of protocol-based care for early septic shock. N Engl J Med 2014, 370:1683-1693.

16. Asfar P, Meziani F, Hamel JF, Grelon F, Megarbane B, Anguel N, Mira JP, Dequin PF, Gergaud S, Weiss N, Legay F, Le Tulzo Y, Conrad M, Robert R, Gonzalez F, Guitton C, Tamion F, Tonnelier JM, Guezennec P, Van Der Linden T, Vieillard-Baron A, Mariotte E, Pradel G, Lesieur O, Ricard JD, Hervé F, du Cheyron D, Guerin C, Mercat A, Teboul JL, et al: High versus low-pressure target in patients with septic shock. N Engl J Med 2014 370:1583-1593.

17. Ait-Oufella H, Bourcier S, Alves M, Galbois A, Baudel JL, Margetis D, Bige N, Offenstadt G, Maury E, Guidet B: Alteration of skin perfusion in mottling area during septic shock. Ann Intensive Care 2013, 3:31. 
18. Ait-Oufella H, Bige N, Boelle PY, Pichereau C, Alves M, Bertinchamp R, Baudel JL, Galbois A, Maury E, Guidet B: Capillary refill time exploration during septic shock. Intensive Care Med 2014, 40:958-964.

19. Woodcock TE, Woodcock TM: Revised Starling equation and the glycocalyx model of transvascular fluid exchange: an improved paradigm for prescribing intravenous fluid therapy. Br J Anaest 2012, 108:384-394.

doi:10.1186/s13054-014-0707-6

Cite this article as: Guidet and Ait-Oufella: Fluid resuscitation should

respect the endothelial glycocalyx layer. Critical Care 2014 18:707. 